\title{
Do Russian paucal numerals govern the genitive? Evidence from stress placement
}

Anonymous authors

\section{Abstract}

A long-standing issue in Russian linguistics concerns the form of the noun in paucal constructions like $d v a$ goroda 'two cities'. Is goroda the genitive singular of gorod, or are we dealing with a separate "numerative case form" or a "paucal number"? Although stress has figured prominently in the debate, corpus data and informant data regarding stress placement have received little attention in the literature. Based on data from the accentuated part of the Russian National Corpus and two small experiments with informants, the present article addresses the locus of stress in rjad 'row', sled 'trace', čas 'hour', šag 'step' and šar 'sphere, ball', as well as nouns where the genitive singular and the nominative plural have the same ending, but different stress placement (e.g. storona 'side'). Four points are made. First, it is demonstrated that a small group of nouns (in particular rjad, čas, and storona) frequently display stress placement that deviates from the genitive, but that the majority of nouns show genitive stress in paucal constructions. Second, an analysis in terms of morphological overdifferentiation is proposed, whereby a small number of nouns have an "extra" inflected form (a numerative case or a paucal number) that is not found in other inflectional paradigms. This analysis enables us to accommodate the attested examples of non-genitive stress without abandoning the main rule that paucal numerals normally combine with nouns in the genitive singular. Third, substantivized adjectives and adjectival agreement are argued not to be at variance with the proposed analysis. Finally, it is suggested that the relevant generalizations can be represented as constructional schemas of the type assumed in Construction Grammar.

\section{One problem, three potential solutions}

The syntax of Russian numerals is notorious for its complexity, and as pointed out by Corbett (1993: 12), most complex are the paucal quantifiers $d v a / d v e$ 'two', tri 'three', četyre 'four', pol 'half', poltora 'one and a half', and oba/obe 'both'. One problem concerns the form of the quantified noun: ${ }^{1}$

(1) Teper' èti dva goroda - glavnye centry našego biznesa v Rossii. (Za rulem, 2004) 'Now these two cities are the main centers of our business in Russia.'

Is goroda in such examples the genitive singular of gorod 'city', or are we dealing with some other form? The traditional analysis that is often found in grammars and handbooks (e.g. Wade 2001:214) is that the noun is indeed in the genitive singular, and this analysis has recently been defended by Andersen (2006). However, two other analyses are also discussed in the literature. Zaliznjak (2002/1967: 46-48, see also Mel'čuk 1985: 430-437) argues that we are instead dealing with a different case, for which he uses the traditional Russian term sčëtnaja forma 'count form'. For the purposes of the present study, we will follow Timberlake (2004: 197-200) and Andersen (2006: 61) and use the English term "numerative" for this proposed case. Yet another analysis maintains that we are not dealing with a separate case, but rather a number,

\footnotetext{
${ }^{1}$ All numbered examples in this article are from the Russian National Corpus (www.ruscorpora.ru). Examples with stress marking are from the accentuated subcorpus, other examples from the main corpus. For the convenience of the reader, the paucal constructions under discussion are boldfaced in the examples. A source and a year are given for each example.
} 
which we may refer to as "paucal" (Corbett 1993: 16, Pereltsvaig 2009: 427, Igartua and Madariaga 2018). ${ }^{2}$

Stress placement has played an important part in the discussion of the three competing analyses. In particular, the five nouns rjad 'row', sled 'trace', čas 'hour', šag 'step' and šar 'sphere, ball' are attested with end stress after paucal numerals (e.g. dva časá 'two hours'), while the normal stress placement in the genitive singular is on the stem (e.g. okolo ćása 'about an hour'). Zaliznjak (2002/1967: 46-48) uses this as an argument in favor of a separate numerative case; since the quantified noun has a stress placement that is different from that of the genitive singular, he argues, we must be dealing with another form.

Until recently arguments like this seem to have been based on introspection. However, we now have access to an accentuated corpus (the accentuated part of the Russian National Corpus), and this makes it possible to investigate the locus of stress in the quantified noun in a more systematic manner. The present study is a first step towards such a systematic investigation.

We will treat the three competing analyses described above as hypotheses, which can be stated as follows:

(2) Genitive Hypothesis: Paucal numerals combine with nouns in the genitive singular.

(3) Numerative/Paucal Hypothesis: Paucal numerals combine with nouns in the numerative case/paucal number.

These hypotheses have different predictions regarding stress placement. If the Genitive Hypothesis is correct, we expect the quantified noun to have the same locus of stress as in (other instances of) the genitive singular. The alternative hypothesis in (3) would lead us to expect a different stress placement - at least for some nouns. It would be possible to divide the hypothesis in (3) into two hypotheses, one for a numerative case and one for a paucal number, but since the data from stress explored in the present study are not sufficient to decide between these two hypotheses, we will treat them as one hypothesis and focus on the assessment of the Genitive Hypothesis, i.e. whether or not it finds support from available corpus and informant data concerning stress placement.

There are two instances of the paucal construction that are of particular interest with regard to the locus of stress. In addition to the construction with the five nouns rjad, sled, čas, šag and $\check{s} a r$, which will be treated in section 2 below, there are numerous nouns which have the same ending in the genitive singular and the nominative plural, but different stress placement, e.g. strana 'country':

(4) Rossija i Švecija - dve evropejskie strany, kotorye imejot davnie xokkejnye tradicii. 'Russian and Sweden are two European countries that have long traditions with ice hockey.' (Izvestija, 2002)

Do native speakers prefer the stress of the genitive singular (straný) or the stress placement of the nominative plural (strány) in such constructions? Genitive stress would be expected on the basis of the Genitive Hypothesis, while nominative stress would be evidence against this hypothesis. There are at least three factors that might motivate the use of nominative plural stress. In addition to the already mentioned fact that the genitive singular and the nominative plural have the same ending for the nouns in question, adjectives modifying feminine nouns

\footnotetext{
${ }^{2}$ A terminological clarification is in order. In the following, "paucal numeral" will be used as a cover term for numerals larger than one and smaller than five and "paucal construction" about the combination of such numerals and a noun phrase. "Paucal number" denotes a postulated value in the morphosyntactic category of number, in addition to singular and plural.
} 
may occur in (what appears to be) the nominative plural (e.g., evropejskie in (4)), and this might prompt nominative plural stress. Finally, the fact that phrases like $d v e$ evropejskie strany refers to more than one country would make them conceptually compatible with the category of plural. We will consider stress in nouns like strana in section 3, where the Genitive Hypothesis is tested against corpus data, as well as data from two small experiments with informants.

In order to investigate the stress placement of nouns in paucal constructions, all examples with $d v a$, tri or četyre immediately followed by a noun were extracted from the accentological subcorpus of the Russian National Corpus (www.ruscorpora.ru). ${ }^{3}$ The results were exported to a spreadsheet and further annotated for gender, stress patterns, time periods and genres. The resulting database contains 22,526 examples from the period 1800-2016. The corpus includes some examples from before 1800 , but they were considered too few for systematic analysis and were not included in the database.

As mentioned, it is possible that adjectives in the nominative plural in examples like (4) may trigger nominative plural stress in the quantified noun. In order to study noun stress in constructions of this type, a second database was set up. All examples with $d v a$, tri or četyre followed by an adjective and a noun were extracted from the accentological subcorpus of the Russian National Corpus and analyzed in the same way as the first database. The resulting database contains 1,015 examples from the period 1800-2016. The data from this database were supplemented with data from two small experiments with native speakers. These experiments will be discussed in sections 3.3 and 3.4 below.

The contribution of the present study is fourfold. First, on the descriptive level the present study shows that stress that deviates from the genitive is dominant in at least three nouns (rjad 'row, čas 'hour', and storona 'side'), but that the overwhelming majority of nouns display genitive stress in the paucal constructions under scrutiny. Second, with regard to the hypotheses in (2)-(3), it is argued that the attested examples of non-genitive stress should be accounted for by marginal rules rather than lexical exceptions. An analysis in terms of overdifferentiation is proposed, which acknowledges that certain nouns have an "extra" form (a "numerative case" or a "paucal number"), but at the same time explicates that the majority of nouns have genitive stress in paucal constructions, as predicted by the Genitive Hypothesis. Third, although the present study focuses on stress, two important issues that go beyond stress placement are considered briefly, and it is argued that they are not at variance with the analysis that was proposed on the basis of the stress facts. Finally, it is shown that the generalizations proposed in this article can be represented as constructional schemas of the type used in Construction Grammar (Goldberg 1995, 2006 and to appear). We follow Goldberg (2013: 29) and adopt an informal version of Construction Grammar, since details of formal representation are tangential to the issues under scrutiny in this article.

The article is structured as follows. Section 2 considers stress in paucal constructions with rjad, sled, čas, šag and $\check{s} a r$, before we turn to stress in constructions like (4) where the genitive singular and nominative plural have the same ending in section 3. After a brief discussion of substantivized adjectives and adjectival agreement in section 4 , the contribution of the proposed analysis is summarized in section 5 .

\section{Evidence from stress 1: The five nouns rjad, sled, čas, šag and šar}

In this section, we consider paucal constructions with the five masculine nouns nouns rjad, sled, $\check{c} a s, \check{s} a g$ and šar. For these nouns, the Genitive Hypothesis predicts stress on the stem in

\footnotetext{
${ }^{3}$ The less frequent numerals pol, poltora and the pronominal quantifier oba/obe were not included in the study. When the search results from the Russian National Corpus are exported to a spreadsheet for further analysis, part of the examples are not transferred to the spreadsheet. In order to lose as few examples as possible we carried out a number of searches for specific time spans, numerals and genders, and then combined the resulting files manually.
} 
paucal constructions since the genitive singular has stem stress (e.g. okolo čása 'about an hour'). To the extent that we find examples with stress on the ending in paucal constructions (e.g. $d v a$ časá 'two hours'), this counts as evidence against the Genitive Hypothesis. After considering the corpus data in section 2.1, we discuss overdifferentiation in section 2.2 and competing constructional schemas in 2.3 , before the Genitive Hypothesis is assessed in section 2.4 .

\subsection{Corpus data}

The corpus data are summarized in Table 1, which contains one row for each noun as well as a bottom row which reports the totals for all five nouns. The column marked "\#GenStress" gives the raw numbers of examples with stem stress characteristic of the genitive singular (e.g. $d v a$ čása), while the raw numbers of examples with end stress are provided in the column marked "\#NonGenStress". The rightmost column marked "\%NonGenStress" gives the percentage of examples with end stress. ${ }^{4}$

\begin{tabular}{lrrr} 
& \#GenStress & \#NonGenStress & \% NonGenStress \\
\hline Rjad 'row' & 11 & 51 & $82 \%$ \\
Sled 'trace' & 1 & 4 & n.a. \\
Čas 'hour' & 113 & 634 & $85 \%$ \\
Šag 'step' & 89 & 59 & $40 \%$ \\
Šar 'sphere, ball' & 2 & 11 & $85 \%$ \\
Total & 216 & 759 & $78 \%$
\end{tabular}

Table 1: Distribution of stress for five nouns in accentuated corpus

The following observations can be made on the basis of Table 1. First, as shown in the bottom row, end stress is attested in $78 \%$ of the examples. In other words, about four out of five nouns have end stress. Second, at least for čas and rjad end stress is the favored option with more than $80 \%$ of the examples, whereas for $\breve{s} a g$ stem stress is the most frequent option (only $40 \%$ of the examples had end stress). For the two remaining nouns, we have too few examples to draw firm conclusions, although the few attested examples suggest that end stress dominates.

Has this situation changed over time? In Table 2, the aggregate data for all five nouns are divided into four fifty-year periods, as well as a period spanning from year 2000 to 2016. These data indicate a slow decrease from $96 \%$ end stress in the first half of the $19^{\text {th }}$ century to $71 \%$ end stress in the first years of the $21^{\text {st }}$ century. However, this result should be taken with a grain of salt - for two reasons. First, the amount of data from the two first periods is quite limited, which makes it difficult to assess the situation in the $19^{\text {th }}$ century. Second, the accentological subcorpus consists of a number of different genres, which are not equally distributed over time. In particular, data from the $19^{\text {th }}$ century are mainly from poetry, while the corpus contains other types of data from more recent times.

\begin{tabular}{rrrr} 
& \#GenStress & \#NonGenStress & \%NonGenStress \\
\hline $1800-1849$ & 1 & 22 & $96 \%$ \\
$1850-1899$ & 1 & 13 & $93 \%$ \\
$1900-1949$ & 21 & 121 & $85 \%$ \\
$1950-1999$ & 44 & 248 & $85 \%$ \\
$2000-2016$ & 148 & 356 & $71 \%$
\end{tabular}

\footnotetext{
${ }^{4}$ Notice that percentages for categories with less than 10 members are not reported in this study, since percentages for such small numbers are not meaningful.
} 
The distribution of stem stress and end stress in different genres is given in Table 3. We use "genre" in a wide sense to distinguish between data of five types. Since the genres are unevenly distributed over time, the time period covered by each genre is given in parentheses in each row. "Poetry" (marked as "xudožestvennaja" in the RNC) includes poetic texts from 1800 and onwards. "Naïve poetry" covers texts from the website Stihi.ru, where anybody is welcome to upload their verses. All this material is from the $21^{\text {st }}$ century. "Reading" is used as a cover term for what the corpus labels "xudožestvennoe čtenie, nexudožestvennaja" and "avtorskoe čtenie, nexudožestvennaja". The examples in the table are from recorded readings of classical works of fiction from the $19^{\text {th }}$ and $20^{\text {th }}$ centuries. "Film \& Theater" covers the categories "kino, nexudožestvennaja" and "teatral'naja reč', nexudožestvennaja" from the corpus. Finally, "Oral speech" is what the corpus calls "ustnaja publičnaja/nepubličnaja reč"”. The examples in the two last genres are from the $20^{\text {th }}$ and $21^{\text {st }}$ centuries.

\begin{tabular}{lrrr} 
& \#GenStress & \#NonGenStress & \%NonGenStress \\
\hline Poetry (1800-2016) & 12 & 177 & $94 \%$ \\
Naïve poetry (2000-2016) & 83 & 206 & $71 \%$ \\
Reading (1800-1999) & 0 & 4 & n.a. \\
Film \& Theater (1900-2016) & 70 & 247 & $78 \%$ \\
Oral speech (1900-2016) & 50 & 126 & $72 \%$ \\
Table 3: Distribution of stress types for five nouns in different genres in accentuated corpus
\end{tabular}

Table 3 shows that poetry has the highest percentage of end stress ( $94 \%$ "NonGenStress"), while the other three genres, for which we have enough data, have between $71 \%$ and $78 \%$ end stress. Does this mean that end stress is less dominant in more informal genres closer to everyday language? Or is this an indication that end stress has become less widespread over time? Since we do not have examples from before 1900 in the less formal genres (naïve poetry, film \& theater, and oral speech), we cannot be sure. However, a likely guess is that both factors are relevant, i.e. that language change toward less end stress has been propelled by everyday speech as reflected in the less formal genres.

Taken together, the data from the three tables suggest that end stress is frequently used for at least three nouns ( $\mathrm{rjad}, \check{c} a s$ and $\check{s} a g$ ), and that it is dominant for two of them: rjad and $\check{c} a s$. Even in the latest period and in the least formal genres approximately three out of four examples have end stress. Although end stress in the relevant nouns is a marginal phenomenon pertaining to a small number of words, the phenomenon is part of what speakers have to master when they acquire Russian, and therefore part of what linguists should include in their descriptions of the language.

\subsection{Overdifferentiation}

In view of the fact that we are dealing with a marginal phenomenon, the question arises as to whether all Russian nouns need to be specified for an additional numerative case or paucal number. In the following, we will instead argue that end stress in rjad, sled, čas, šag and šar can be insightfully analyzed as an example of morphological overdifferentiation.

The term "overdiffentiation" in morphology, which goes back to Bloomfield (1933: 223224), refers to the situation where a paradigm contains an extra form that realizes "an additional value of an already attested feature in the class or subclass of the items in question" (Corbett 2007: 31). The classic example is the English verb be. While in the present tense most English verbs have the feature "person" ( $I$, you sing vs. s/he sings), be realizes the additional value "first" (I am, see Stump 2015: 155-157 for extensive discussion). An analysis in terms of overdifferentiation makes it possible to avoid massive syncretism. Instead of postulating for all 
English verbs a separate first person singular form that just happens to be syncretic with the second person for all but one verb, we can say that be has a larger paradigm than other English verbs.

In Russian linguistics, overdifferentiation has been invoked in the analysis of the second locative, and Brown (2007) has demonstrated how an analysis along these lines can be implemented formally. While Russian nouns in general have one locative (prepositional) case ( $v$ knige 'in the book'), some nouns have an additional distinction between the "normal" locative (v snege) and the "second locative" (v snegu, Jakobson 1936). We avoid massive syncretism if we assume that nouns like sneg have a larger paradigm than the majority of nouns, such as kniga. It is worth pointing out that the second locative resembles the issue under discussion in the present study, since stress placement is important for both phenomena. The second locative is always end-stressed, and in the third declension stress is the only marker distinguishing between the two locative cases ( $o$ dvéri 'about the door' vs. $v d v e r i$ 'in the door'). Another similarity between the second locative and the phenomenon under scrutiny in the present study is that both categories involve optionality. For many nouns, the use of the second locative form is optional in the same way as the nouns in Table 1 above display variation between stem stress and end stress.

It is not clear how marginal a phenomenon needs be in order for an analysis in terms of overdifferentiation to be preferable, but end stress in the nouns under discussion is not far removed from the extreme example of the isolated be in English since we are dealing with a category of only five words (not all of which show non-genitive stress consistently). Moreover, if one accepts an overdifferentiation analysis for the Russian second locative, a category that consists of about a hundred nouns (Zaliznjak 1977, Brown 2007: 64), one surely must accept a similar analysis for the much more peripheral phenomenon under scrutiny in the present study which involves as few as five words.

\subsection{Idiomatic lexical excpetions or marginal rules in the grammar? Constructional schemas}

Some analysts might be inclined to go even further and write end stress in rjad, sled, čas, šag and šar off as idiomatic exceptions that belong in the lexicon, rather than in the grammar (see Zaliznjak 2002/1967: 47 and Andersen 2006: 61 for discussion). But where do we draw the line between marginal syntactic rules in the grammar and idiomatic exceptions in the lexicon? It seems impossible to avoid making arbitrary decisions, since idiomaticity is a matter of degree (see e.g. Michaelis 2017). However, the problem disappears if we adopt a linguistic model where there is no clear-cut division line between lexicon and grammar, such as Construction Grammar and other varieties of cognitive linguistics (see e.g. Langacker 2008: 21-24 for discussion). In such models, both what is traditionally considered lexicon and grammar are conceived of as a "constructicon", i.e. a large network of constructional schemas of different degrees of specificity (Janda et al. 2018). Informally, for constructions with paucal numerals we can assume two constructional schemas:

(5) a. rjad, sled, čas, šag, šar: Paucal numeral + noun in the genitive singular (but with end stress)

b. Elsewhere: Paucal numeral + noun in the genitive singular

The specific schema in (5a) states that the paucal constructions for the five listed nouns have normal genitive forms, but with the additional specification that stress falls on the ending. This specification is placed in parentheses since end stress is not obligatory. ${ }^{5}$ The constructional

\footnotetext{
${ }^{5}$ We here disregard differences among the five nouns. While a more fine-grained analysis with several constructional schemas is possible, the relevant details do not contribute to the argument, and are therefore not included in the constructional schemas in (5).
} 
schema in (5b) represents the default pattern, whereby paucal numerals combine with genitive singular forms of nouns.

One detail is worth mentioning. The specific constructional schema in (5a) refers to the "genitive singular" instead of the "numerative case" or the "paucal number". It would indeed be possible to use "numerative" or "paucal" in the schema, but the version in (5a) has the advantage of expressing the generalization that the paucal numeral is followed by a form that is identical to the genitive singular, except that stress optionally falls on the ending.

Before we leave the constructional schemas in (5) it is worth pointing out that there is independent evidence for such schemas regardless of how we analyze rjad, sled, čas, šag and $\check{s} a r$. By way of example consider the stress in numerals like pjat' 'five'. While such numerals have immobile end stress with instrumental forms like pjat'jú (s pjat'jú studéntami 'with five students'), in the particular "multiplication construction" stress is on the stem (pját'ju pjat' "five multiplied by five', see e.g. Wade 2001: 238). In order to account for the deviant stress in the multiplication construction, we need a constructional schema that captures the stress placement in this construction in addition to a general schema for the stress pattern of numerals like pjat'. Whether the constructional schema for the multiplication construction implies that Russian has a "second instrumental" akin to the second locative case is a question that is beyond the scope of the present study.

\subsection{Assessment of the Genitive Hypothesis}

Where does the proposed analysis take us with regard to the hypotheses presented in section 1 ? The Genitive Hypothesis predicts that the noun in paucal constructions has the same stress placement as "normal" genitive singular forms. This is true for the overwhelming majority of Russian nouns. At the same time, the five nouns explored above do display a different stress placement, although it appears not to be obligatory, at least not for all nouns in all genres. It follows from this that there is such an exceptional phenomenon as the "numerative" or "paucal", which can be accounted for by means of a specific schema such as (5a). Even if we may not use "numerative" or "paucal" in the relevant constructional schemas, as linguists we may use these labels to refer to the phenomenon. Importantly, however, even if we accept the existence of the "numerative" or "paucal", we can still maintain the main rule in $(5 \mathrm{~b})$ that paucal numerals combine with the genitive singular, as predicted by the Genitive Hypothesis.

\section{Evidence from stress 2: Other nouns with mobile stress}

We now turn to the second situation where stress is relevant for paucal constructions. As pointed out in section 1, there are a number of nouns that have the same ending in the genitive singular and the nominative plural, but differ in stress, e.g. strana 'country'. The question therefore arises as to whether language users prefer genitive stress (as predicted by the Genitive Hypothesis) or deviate from this stress placement, as the Numerative/Paucal Hypothesis would lead us to expect. The four case studies in subsections 3.1 through 3.4 indicate that genitive stress is the preferred option, but that deviations do occur. However, only for one word, storona 'side', is non-genitive stress dominant.

\subsection{Corpus data 1: Nouns with mobile stress}

In the following we are interested in all nouns that have the same ending, but different locus of stress in the genitive singular and nominative plural:

(6) a. All masculine first declension nouns with mobile stress and the ending $-a /-j a$ in the genitive singular and nominative plural (e.g. les 'forest': genitive singular lésa vs. nominative plural lesá)

b. All neuter first declension nouns with mobile stress and the ending $-a /-j a$ in the genitive singular and nominative plural (e.g. mesto 'place': genitive singular mésta 
vs. nominative plural mestá, and okno 'window': genitive singular okná vs. nominative plural ókna)

c. All second declension nouns with mobile stress and the ending $-y /-i$ in the genitive singular and nominative plural (e.g. strana 'country': genitive singular straný vs. nominative plural strány, and storona 'side': genitive singular storoný vs. nominative plural stórony)

By "mobile stress" is here meant Zaliznjak's pattern (2002/1967) c as in les and mesto, pattern $\mathrm{d}$ as in okno and strana, and pattern $\mathrm{f}$ as in storona. Pattern a (immobile stem stress) and pattern b (immobile end stress) are not relevant, and the same holds for pattern e, which involves the same locus of stress in the genitive singular and the nominative plural, as in kost' 'bone' (genitive singular and nominative plural kósti).

Table 4 shows aggregate numbers from the accentuated corpus for all three types of noun described in (6). As mentioned in section 1, we are concerned with constructions where a paucal numeral ( $d v a$, tri, četyre) is immediately followed by a noun. As shown, nominative stress is attested in all declensions, but never in more than $10 \%$ of the examples.

\begin{tabular}{lrrr} 
& \#GenStress & \#NomStress & \%NomStress \\
\hline First declension masculine & 1887 & 63 & $3 \%$ \\
First declension neuter & 1509 & 92 & $6 \%$ \\
Second declension feminine & 1100 & 109 & $9 \%$ \\
Total: all declensions/genders & 4496 & 264 & $6 \%$
\end{tabular}

Table 4: Stress of quantified noun for different declensions/genders

Here is one example with nominative stress (tri svéči instead of tri sveči) from oral speech:

(7) Mý tóže tudá $v$ cérkov’ zašlí / svéči zažigáli rodíteljam [...] trí svéči postávila já vot. (from the TV show "Pis'ma iz provincii", 2009)

'We went to the church to / lit candles for our parents [...] three candles I placed there.'

The speaker, a woman from Tatarstan, first mentions the nominative plural svéči 'candles', and afterwards uses the same stress placement when the noun follows the numeral tri. In this particular example, it is possible that we are dealing with a priming effect, whereby the use of nominative stress earlier in the utterance influences the stress placement in the following paucal construction. However, priming effects are not at stake in all relevant examples.

Table 5 presents aggregate data for different periods of time. As shown, the situation appears to have been relatively stable over the past two centuries.

\begin{tabular}{lrrr} 
& \#GenStress & \#NomStress & \%NomStress \\
\hline $1800-1849$ & 201 & 13 & $6 \%$ \\
$1850-1899$ & 150 & 14 & $9 \%$ \\
$1900-1949$ & 881 & 17 & $2 \%$ \\
$1950-1999$ & 745 & 22 & $3 \%$ \\
$2000-2016$ & 2519 & 198 & $7 \%$ \\
Total: all periods & 4496 & 264 & $6 \%$
\end{tabular}

Table 5: Stress of quantified noun for different time periods

As mentioned in section 2.1, the accentuated subcorpus of the Russian National Corpus is heterogeneous with regard to genres, and it is therefore relevant to consider the five genres 
described in 2.1 separately. However, Table 6 indicates that there are very small differences between genres.

\begin{tabular}{lrrr} 
& \#GenStress & \#NomStress & \%NomStress \\
\hline Poetry & 1376 & 47 & $3 \%$ \\
Naïve poetry & 1814 & 189 & $9 \%$ \\
Reading & 20 & 1 & $5 \%$ \\
Film\&Theater & 649 & 19 & $3 \%$ \\
Oral speech & 637 & 8 & $1 \%$ \\
Total: all genres & 4496 & 264 & $6 \%$
\end{tabular}

Table 6: Stress of quantified noun for different genres

Table 7 shows the situation for different stress patterns. ${ }^{6}$ On the face of it, the numbers suggest that pattern $\mathrm{f}$ has a much higher proportion of nominative stress. However, upon closer inspection responsible for this is one single noun, storona 'side', to which we return below.

\begin{tabular}{lrrr} 
& \#GenStress & \#NomStress & \%NomStress \\
\hline Mobile c & 2828 & 122 & $4 \%$ \\
Mobile d & 1353 & 63 & $4 \%$ \\
Mobile d/f & 43 & 1 & $2 \%$ \\
Mobile f & 272 & 78 & $22 \%$ \\
Total: all patterns & 4496 & 270 & $6 \%$
\end{tabular}

Table 7: Stress of quantified noun for different stress patterns

Since no declension class, time period, genre or stress pattern strongly favors nominative stress, it is necessary to consider individual nouns. Table 8 shows all nouns with more than $10 \%$ nominative stress and 10 or more attestations. The threshold of at least 10 attestations was adopted in order to exclude nouns with few attested examples, for which it is impossible to draw firm conclusions. The table contains a heterogeneous group of 11 nouns from all relevant declension classes, genders and stress patterns, so nominative stress does not seem connected to a natural class of nouns that could be defined with regard to their content or form. Admittedly, the table contains a couple of paired objects (bereg 'riverbank' and glaz 'eye'), but other paired nouns with relevant stress properties such as noga 'leg' and ruka 'hand' are not on the list, so it would be far-fetched to postulate a connection between paired objects and nominative stress. Likewise, although the table contains some nouns with the pleophony ("polnoglasie") sound sequences -ere-, -olo- and -oro- (bereg 'riverbank', golova 'head', storona 'side'), there are other nouns with similar form that are not on the list, e.g. polosa 'stripe', sloboda 'settlement', and borozda 'furrow', so assuming a relationship between pleophony and nominative stress seems unlikely.

\footnotetext{
6 "Mobile d/f" refers to nouns that according to Zaliznjak (2002/1967) vacillate between patterns d and f: volna 'wave', zarja 'dawn', stroka 'line', and strofa 'verse'.
} 


\begin{tabular}{lllrrr} 
& Decl./gender & $\begin{array}{l}\text { Stress } \\
\text { pattern }\end{array}$ & \#GenStress & \#NomStress & \%NomStress \\
& & c & 23 & 7 & $23 \%$ \\
\hline Bereg 'riverbank' & First masc. & c & 51 & 6 & $11 \%$ \\
Glaz 'eye' & First masc. & $\mathrm{c}$ & 18 & 6 & $25 \%$ \\
Tom 'volume' & First masc. & $\mathrm{c}$ & 24 & 3 & $11 \%$ \\
Lico 'face, person' & First neuter & $\mathrm{d}$ & 9 & 1 & $10 \%$ \\
Petlja 'loop' & Sec. feminine & $\mathrm{d}$ & 16 & 3 & $16 \%$ \\
Pis'mo 'letter' & First neuter & $\mathrm{d}$ & 43 & 8 & $16 \%$ \\
Stena 'wall' & Sec. feminine & $\mathrm{d}$ & 14 & 2 & $13 \%$ \\
Struna 'string' & Sec. feminine & $\mathrm{d}$ & 12 & 2 & $14 \%$ \\
Golova 'head' & Sec. feminine & $\mathrm{f}$ & 58 & 8 & $12 \%$ \\
Sveča 'candle' & Sec. feminine & $\mathrm{f}$ & 38 & 62 & $62 \%$ \\
Storona 'side' & Sec. feminine & $\mathrm{f}$ & & &
\end{tabular}

Table 8: Stress of quantified noun from different stress patterns

Since it does not seem possible to state any generalizations over groups of words, what we are left with in Table 8 is a list of individual nouns with idiosyncratic accentual behavior. Of these nouns, only three (bereg 'riverbank', tom 'volume', and storona 'side') display more than $20 \%$ nominative stress, and only one (storona) has nominative stress in more than $50 \%$ of the attested examples. Let us take a closer look at these three nouns.

Monosyllabic masculine nouns in the first declension like tom are particularly complex when it comes to stress placement. As Zaliznjak (2002/1977: 484-485) has shown, such nouns often receive end stress in the speech of individuals for whom the relevant nouns are familiar (Russian: privyčnyj) and who therefore use them frequently. For instance, as pointed out by Zaliznjak (2002/1977: 484), although špric 'syringe' according to the literary norm has immobile stem stress (pattern a), medical doctors and other professionals who use the word frequently in their everyday speech often use end stress. In view of this, corpus examples like tomá may be interpreted as end stressed genitive forms in "professional speech", i.e. the immobile end stress pattern $b$. The following example is arguably of this kind. Here, the lexicographer M. Vasmer describes his famous etymological dictionary at the International Congress of Slavists in Moscow in 1958:

(8) Nó já vméste s tem bojálsja slíškom bol’šógo ob"ëma moegó slovarjá. I tak užé trí tomá. (M. Vasmer at the International Congress of Slavists, 1958)

'But at the same time I was afraid that my dictionary would become too big. And I already had three volumes.'

In view of the fact that end stress may be due to professional speech, forms like tomá are not unequivocal examples of nominative stress and therefore cannot be interpreted as evidence against the Genitive Hypothesis.

End stress in professional speech is mainly an option for monosyllabic nouns, so forms like beregá are more likely to be genuine examples of nominative stress. Several examples in the accentuated corpus involve versions of the cliché my s toboj dva berega odnoj reki 'we are two banks of the same river', which is attested with both genitive stress (bérega) and nominative stress (beregá). A possible reason why the proportion of nominative stress is high for this noun, is the fact that all but four examples happen to be from naïve poetry, which is the genre that is most prone to showing nominative stress.

It is not surprising that storona shows the highest proportion of nominative stress, because this noun is often mentioned as an example of idiosyncratic stress in paucal constructions (see 
e.g. Andersen 2006: 61). Zaliznjak (1977) remarks that there is vacillation between stem stress and end stress in the fixed expression na vse četyre stórony/storoný 'in all four directions'. If we factor out the examples with this idiomatic construction, the situation is as shown in Table 9. For the fixed expression, nominative stress dominates with $85 \%$, while in other contexts we find nominative stress in $42 \%$ of the attested examples. In other words, although the proportion of nominative stress is highest for the idiomatic expression, nominative stress is not limited to this expression.

\begin{tabular}{lrrr} 
& \#GenStress & \#NomStress & \%NomStress \\
\hline Na (vse) četyre storony & 7 & 40 & $85 \%$ \\
Other contexts & 31 & 22 & $42 \%$ \\
Total: all contexts & 38 & 62 & $62 \%$ \\
Table 9. Stress of storona 'side' in different contexts & &
\end{tabular}

How can we account for the data presented in this subsection? Clearly, the general pattern is that the relevant nouns show genitive stress, as predicted by the Genitive Hypothesis. A small number of individual nouns display nominative stress to various degrees. It may be tempting to write them off as lexical exceptions attested in idiomatic expressions. However, as we have seen, stem-stressed stórony is not limited to one idiomatic expression. Moreover, if we assume a constructional schema for the five nouns rjad, sled, čas, šag and šar, why not assume one for storona (and, possibly, a few other nouns)? In both instances, we are dealing with marginal, but not completely unsystematic facets of Russian grammar. We propose to supplement the constructional schemas in (5) with an additional schema for storona:

(9) storona: Paucal numeral + storoný or stórony (stórony especially in the expression na (vse) četyre storony)

This can be analyzed as another example of (facultative) overdifferentiation, and the addition of the schema in (9) therefore does not force us to assume that all nouns have forms different from the genitive in paucal constructions. The general rule is that paucals combine with nouns with genitive stress, as predicted by the Genitive Hypothesis.

\subsection{Corpus data 2: Influence from nominative adjectives?}

In section 1 we saw that paucal numerals may combine with adjectives in (what on the surface looks like) the nominative (dve evropejskie strany 'two European countries'), which compete with genitive adjectives (dve evropejskix strany). Do nominative adjectives increase the chances of nominative stress in paucal constructions? As we will see in this subsection, the evidence from the accentological subcorpus of the Russsian National Corpus suggests that the answer is in the negative.

Table 10 summarizes the situation for all examples with a paucal numeral followed by an adjective and a feminine noun in the second declension (which is the only declension where adjectives display competition between the nominative and genitive forms in present-day Russian, Nesset submitted). As the table shows, the difference in noun stress between nouns preceded by adjectives in the nominative and genitive is negligible.

\begin{tabular}{lrrr} 
& \#GenStress & \#NomStress & \%NomStress \\
\hline Nominative adjective & 108 & 13 & $11 \%$ \\
Genitive adjective & 72 & 8 & $10 \%$ \\
Total & 180 & 21 & $10 \%$
\end{tabular}

Table 10: Distribution of genitive and nominative stress on nouns preceded by adjective in the nominative vs. gentive case 
Of the 21 examples with Nominative stress, 18 are from "naïve poetry" from the 21 century, which lends further support to the observation made in the previous subsection that this genre and time period are favorable for nominative stress. Nominative stress is distributed relatively evenly across 11 nouns (number of examples with nominative stress in parentheses):

(10) glava 'chapter, leader' (1), duša 'soul' (6), zvezda 'star' (2), plita 'stove' (1), prostynja 'bedsheet' (1), sveča 'candle' (3), sem 'ja 'family' (1), stena 'wall' (1), storona 'side' (2), sud'ba 'fate' (2), trava 'grass' (1)

These nouns do not constitute a natural class, so it seems difficult to make any generalizations. In view of this, we only suggest constructional schemas for nouns with genitive stress:

(11) a. Feminine nouns: Paucal numeral + adjective in -ye/-ie $(-y x /-i x)+$ noun in the genitive singular

b. Elsewhere: Paucal numeral + adjective in $-y x /-i x+$ noun in the genitive singular

The schema in (11a) covers feminine nouns, for which there is a competition between adjectives in -ye/-ie and $-y x /-i x$. The latter ending is placed in parentheses since adjectives in -ye/-ie are in the process of outcompeting $-y x /-i x$ in the feminine gender (Nesset submitted, see also Pereltsvaig 2009 and Madariaga and Igartua 2017: 101). The schema in (11b) accommodates paucal constructions with masculine and neuter nouns, where $-y x /-i x$ is the only option in Contemporary Standard Russian (Nesset submitted).

\subsection{Informant data 1: Filling in adjectives}

In order to find out more about the relationship between the form of the adjective and the stress placement on the noun, a small experiment with informants was carried out on Sakhalin in July 2016. Forty-six native speakers were presented with sentences with a paucal numeral followed by an open space and a noun, and they were asked to fill in an adjective in the open space and read the sentence, which was recorded. This prompted informants to focus on coming up with a suitable adjective, rather than thinking about the grammatical form of the adjective or the locus of stress on the noun. The experiment involved 8 nouns with mobile stress and 36 fillers.

Table 11 reports on the situation for all non-fillers. The results differ from the corpus data presented in the previous subsection in two ways. First, the proportion of nominative stress is slightly higher than in the corpus data. Second, it seems that a genitive adjective blocks the possibility of nominative stress, which is interesting, since it goes against the corpus data in Table 10 above.

\begin{tabular}{lrrr} 
& \#GenStress & \#NomStress & \%NomStress \\
\hline Nominative adjective & 203 & 41 & $17 \%$ \\
Genitive adjective & 62 & 0 & $0 \%$ \\
Total & 265 & 41 & $13 \%$
\end{tabular}

Table 11: Distribution of stress types for different forms of adjectives in informant data from Sakhalin

The use of nominative stress is not evenly distributed among the nouns that were tested in the experiment, as shown in Table 12. Again, the results differ from the corpus data discussed in the previous subsection, although the noun with the highest proportion of nominative stress in the experiment, golova 'head', is also among the nouns that are attested with nominative stress in the corpus, as shown in Table 8 in section 3.1. 


\begin{tabular}{lrrr} 
& \#GenStress & \#NomStress & \%NomStress \\
\hline Golova 'head' & 21 & 18 & $46 \%$ \\
Gora 'mountain' & 31 & 8 & $21 \%$ \\
Strana 'country' & 33 & 6 & $15 \%$ \\
Ruka 'arm, hand' & 32 & 5 & $14 \%$ \\
Beda 'misfortune' & 36 & 3 & $8 \%$ \\
Zima 'winter' & 35 & 1 & $3 \%$ \\
Žena 'wife' & 38 & 0 & $0 \%$ \\
Sestra 'sister' & 39 & 0 & $0 \%$ \\
Total & 265 & 41 & $13 \%$ \\
Table 12: Distribution of stress types for individual nouns in informant collected on Sakhalin
\end{tabular}

Drawing firm conclusions from a small-scale experiment is dangerous, but it is interesting that the experiment was conducted far away from the centers of the literary language in Moscow and Petersburg. It is possible that in everyday speech in such areas the use of nominative stress, especially in combination with an adjective in the nominative, is more widespread than what corpus data suggest. However, before we conclude we will consider data from another experiment which included three of the nouns in Table 12.

\subsection{Informant data 2: Reading and responding to sentences}

This experiment was carried out with 34 native speakers of Russian (16 males and 18 females) during the conference Arctic Forum in Arkhangelsk between March 27 and April 2, 2017. The informants lived in different parts of Russia and were between 21 and 35 years old when the experiment was carried out. The informants were presented with a paper with three sentences, which they were told to read out loud before they responded to them:

(12) a. Kak vy oxarekterizovali by tri poslednie zimy v vašem rodnom krae? 'How would characterize the three last winters in your home areas?'

b. Nazovite tri evropejskie strany, v kotorye vy xoteli by s' 'ezdit'. 'Name three European countries you would like to travel to.'

c. A znaete li vy, čto u norvežskix trollej možet byt' tri živyx golovy? 'Do you know that Norwegian trolls may have three live heads?'

The experiment was set up in such a way that the informants would pay attention to their responses, instead of the sentences with the paucal constructions of relevance for the present study. The results are presented in Table 13. ${ }^{7}$ Two observations can be made. First, the use of nominative stress is somewhat less widespread in this experiment than in the one reported on in the previous subsection. Second, the order of the nouns is different. In the previous experiment, golova displayed the highest proportion of nominative stress, whereas in this experiment it shows the lowest proportion. This may, however, be due to the fact that the question with golova had the preceding adjective in the genitive, which may have inhibited the use of nominative stress, as suggested by the previous experiment.

\footnotetext{
${ }^{7}$ Notice that although all informants responded to all three sentences, in a few cases it was difficult to decide from the recording where they placed the stress, and these examples were therefore not included in the table.
} 


\begin{tabular}{lrrr} 
& \#GenStress & \#NomStress & \%NomStress \\
\hline Tri poslednie zimy 'three last winters' & 27 & 4 & $13 \%$ \\
Tri evropejskie strany 'three European & 32 & 1 & $3 \%$ \\
countries' & 33 & 1 & $3 \%$ \\
Tri živyx golovy 'three live heads' & 92 & 6 & $6 \%$ \\
Total: all sentences & & \\
Table 13: Distribution of stress types in informant data collected in Arkhangelsk &
\end{tabular}

As observed in the previous subsection, it is problematic to draw firm conclusions from such a limited amount of data, especially since the data from the two experiments do not converge. However, what both experiments show is that genitive stress is dominant, although nominative stress occurs occasionally, at least when a preceding adjective is in the nominative. We will not propose constructional schemas for nominative stress, although it is possible that such schemas are part of some speakers' mental grammars.

\subsection{Assessment of the Genitive Hypothesis}

The data from corpus and informants discussed in the previous subsections suggest that the overwhelming majority of nouns prefer genitive stress, as predicted by the Genitive Hypothesis. Admittedly, nominative stress does occur, albeit not very systematically, and appears to be dominant for only one noun - storona 'side'. It is possible that adjectives in the nominative facilitate nominative stress, and that nominative stress is blocked by genitive adjectives, but the available data do not permit firm conclusions.

\section{Beyond stress: a view from Construction Grammar}

Although the present study focuses on stress, a brief discussion of other arguments is in place, since Zaliznjak (2002/1967: 47) emphasizes that his analysis in terms of the numerative case does not hinge on stress. Two phenomena are of particular interest:

(13) a. Substantivized adjectives, e.g. stolovaja 'cafeteria' and masterskaja 'workshop'

b. Adjectival agreement, especially examples like tri evropejskie strany 'three European countries' with the nominative plural form of the adjective

Substantivized adjectives, i.e. nouns that are inflected in the same way as adjectives, occur in paucal constructions in what appears to be plural forms. Masculine and neuter nouns have genitive plural forms (tri glasnyx 'three vowels', tri nasekomyx 'three insects'), while for feminine nouns both genitive plural and nominative plural forms are attested (tri masterskix vs. tri masterskie 'three workshops'). Zaliznjak (2002/1967) and Pereltsvaig (2009) take this as evidence that the nouns in paucal numerals are not in the genitive singular, and they argue that this goes against the Genitive Hypothesis. Andersen (2006), on the other hand, interprets the behavior of substantivized adjectives as evidence in favor of the Genitive Hypothesis. He observes (as does Zaliznjak 2002/1967: 46 in a footnote) that in some languages numerals combine with nouns in the plural (e.g. English), while in other languages numerals take nouns in the singular (e.g. Hungarian, Estonian and other Finno-Ugric languages). Andersen (2006: 61) argues that Russian occupies an intermediate position where singular and plural nouns both occur in numeral constructions and are in complementary distribution: plural forms are used if the noun co-occurs with a numeral higher than 4 or the noun is inflected like an adjective.

However one assesses Andersen's argument, it cannot be considered coincidental that it is substantivized adjectives that display plural forms in the paucal constructions, because adjectival modifiers also are attested in the plural: 
(14) a. tri novyx magazina $\sim$ tri nasekomyx

b. tri evropejskie strany $\sim$ tri masterskie

The descriptive generalization is that substantivized adjectives occur in the same form as adjectives in paucal constructions. In view of this, it seems that the problem of substantivized adjectives in (13a) can be considered a sub-case of the problem of adjectival agreement in (13b), to which we now turn.

From the perspective of Construction Grammar, the agreement problem boils down to two questions:

(15) a. Which forms combine with which forms?

b. What do the forms in a construction mean, i.e. which grammatical features do the forms carry?

The first problem is accounted for by means of constructional schemas of the type proposed earlier in this study. What language learners need to master with regard to adjectives in paucal constructions, is the fact that the adjective ends in $-y x /-i x$, and that it may also have the ending $-y e /-i e$ if the quantified noun is feminine. These generalizations are captured by the schemas in (11) above.

With regard to the second problem concerning the meaning and grammatical features/categories involved, let us go back to the example of $d v a \check{c} a s a$, before we approach adjectival agreement. What does end stress mean, i.e. what features does it carry? From the perspective of Construction Grammar, grammatical categories/features are shorthand for networks of meanings or functions. For instance, "genitive" is shorthand for a network covering all the meanings/functions genitive phrases occur in. One such network for the Russian genitive has been proposed by Janda and Clancy (2002), but we do not have to be committed to this particular network, as long as we assume a network that covers all the uses of the genitive, including numeral constructions. If we now ask what end stress in e.g. $d v a$ časá means or signals, we first make the observation that end stress restricts the phrase to a subset of the genitive network, namely the part that concerns paucal constructions. This sub-network is the meaning of end stress in the relevant construction. The language users do not need a label for the meaning, but as linguists we might want to use labels such as "numerative" or "paucal" for the phenomenon at hand.

Adjectives, especially those in -ye/-ie pose a somewhat more complicated problem, because $-y e /-i e$ is normally the marker of nominative plural. If we combine an adjective in the nominative plural with a noun in the genitive singular, the result is a feature clash. In Construction Grammar similar clashes involving lexical items are well known, the classic example being Goldberg's (1995: 9) he sneezed the napkin off the table where the intransitive verb sneeze is used in a construction that normally requires a transitive verb. This is called "coercion" - the verb is coerced into a construction where it normally would not be expected to occur (Goldberg 1995: 159, Steels 2013: 167). If the verb gets conventionalized in the relevant construction, the result is a polysemous verb with both an intransitive and a transitive function.

The example with adjectives in -ye/-ie is parallel, although it concerns a grammatical marker, not a lexical item. The grammatical marker has the meaning "nominative plural", but gets coerced into the paucal construction, which yields a feature clash. Despite this the construction has been conventionalized in Russian. As shown in Nesset (submitted, see also Pereltsvaig 2009), the use of -ye/-ie has increased dramatically in the last decades of the twentieth century and has now nearly ousted its competitor, $-y x /-i x$, for feminine nouns. It is thus reasonable to assume that $-y e /-i e$ has undergone conventionalization and become polysemous, i.e. that a new function has been added to its network of meanings. 
How can we characterize this new function? What does the use of adjectives in -ye/-ie signal in paucal constructions? Since -ye/-ie only combines with feminine nouns, a language user can infer from the presence of $-y e /-i e$ that the following noun is feminine. This parallels well-known examples of feminine agreement such as evropejskaja strana, where the ending -aja on the adjective indicates that the following noun is feminine. In view of this, we propose that $d v e$ evropejskie strany is an example of gender agreement on a par with (odna) evropejskaja strana. The generalizations that language users have to acquire are:

(16) a. "-ye/-ie is a nominative plural marker, except in paucal constructions where it marks feminine gender".

b. "Feminine gender is normally marked with -aja/-jaja (and other case forms of this ending), except in paucal constructions where feminine gender is marked by means of $-y e /-i e "$

While the analysis we propose of -ye/-ie as a feminine marker may seem unconventional, it does accommodate the relevant facts, and shows that the behavior of substantivized adjectives and adjectival agreement is not at variance with the behavior of stress in paucal constructions.

\section{Concluding remarks}

Through an empirical investigation of corpus data and data from informants, the present study has provided new insights about stress placement in Russian paucal constructions and explored the consequences of this for our understanding of these constructions in general. First, it has been demonstrated that the majority of nouns display genitive stress in paucal constructions, but that non-genitive stress dominates for at least three nouns, viz. rjad, čas, and storona.

Second, the article has examined the Genitive Hypothesis, according to which the noun in paucal constructions is in the genitive case and compared it to the competing Numerative/Paucal Hypothesis. It has been shown that the majority of nouns display genitive stress, and that the examples of non-genitive stress should be accounted for in terms of marginal rules, rather than lexical exceptions. An analysis in terms of overdifferentiation has been proposed, which acknowledges that certain nouns have an "extra" form (a "numerative case" or a "paucal number"), but at the same time explicates that the majority of nouns have genitive stress in paucal constructions, as predicted by the Genitive Hypothesis.

Although the main topic of this article is the locus of stress in nouns, a third contribution concerns substantivized adjectives and adjectival agreement. It has been shown that substantivized adjectives behave like adjectives in paucal constructions, and we have argued that adjectives are not at variance with the proposed analysis of stress placement on the quantified noun.

This article's final contribution relates to linguistic theory. It has been shown that the generalizations discussed in the present article may be represented as constructional schemas of the type assumed in Construction Grammar and other varieties of cognitive linguistics. The relevant schemas accommodate both the general rule (genitive stress) and the marginal occurrence of non-genitive stress in certain nouns.

A number of questions must be left open for further investigation. Although the accentuated part of the Russian National Corpus represents an important and valuable resource, the corpus is relatively small, and especially data from oral speech is underrepresented. For this reason, data from larger psycholinguistic experiments than the ones reported on in the present article are likely to shed new light on stress placement in paucal constructions. A particularly pertinent question regards the interaction of the form of the adjective and stress placement in the quantified noun. Do adjectives in the nominative plural (dve evropejskie strany) facilitate nongenitive stress (strány), and do genitive adjectives (dve evropejskix strany) block such stress? 
The data explored in the present study do not provide clear answers. While this study represents a first step towards a more systematic study of stress in paucal constructions, these constructions still leave us with work to do.

\section{References}

Andersen, Henning (2006): Some Thoughts on the History of Russian Numeral Syntax. In RUS' WRIT LARGE: LANGUAGES, HISTORIES, CULTURES: Essays Presented in Honor of Michael S. Flier on His Sixty-Fifth Birthday (=Harvard Ukrainian Studies 28.1/4): 5767.

Bloomfield, Leonard (1933): Language. New York: H. Holt and Company.

Brown, Dunstan (2007): Peripheral functions and overdifferentiation: The Russian second locative. Russian Linguistics 31.1: 61-76.

Corbett, Greville G. (1993): The head of Russian numeral expressions. In: Greville G. Corbett, Norman M. Fraser and Scott McGlashan: Heads in grammatical theory. Cambridge: Cambridge University Press.

Corbett, Greville G. (2007: Canonical typology, suppletion and possible words. Language 83.1: 8-42.

Goldberg, Adele E. (1995): Constructions. Chicago: The University of Chicago Press. Goldberg, Adele E. (2006): Constructions at work. Oxford: Oxford University Press.

Goldberg, Adele E. (2013): Constructionist Approaches. In Thomas Hoffmann and Graeme Trousdale (eds.): The Oxford Handbook of Construction Grammar. Oxford: Oxford University Press, 15-31.

Goldberg, Adele E. (to appear): Explain me this. Princeton: Princeton University Press. Igartua, Ivan and Nerea Madariaga (2018): The interplay of semantic and formal factors in Russian morphosyntax: animate paucal constructions in direct object function. Russian Linguistics 42: 27-55

Jakobson, Roman O. (1936): Beitrag zur allgemeinen Kasuslehre. Travaux du Cercle Linguistique de Prague 6: 240-288.

Janda, Laura A. and Steven J. Clancy (2002): The Case Book for Russian. Columbus, Ohio: Slavica.

Janda, Laura A., Olga Lyashevskaya, Tore Nesset, Ekaterina Rakhilina, Francis M. Tyers (2018): A Constructicon for Russian: Filling in the Gaps. In: Benjamin Lyngfelt, Tiago Timponi Torrent, Lars Borin \& Kyoko Hirose Ohara (Eds.): Constructicography: Constructicon development across languages. Amsterdam: John Benjamins.

Langacker, Ronald W. (2008): Cognitive Grammar: A Basic Introduction. Oxford: Oxford University Press.

Madariaga, Nerea and Iva Igartua (2017): Idiosyncratic (Dis)agreement Patterns: The Structure and Diachrony of Russian Paucal Subjects. Scando-Slavica 63:2: 99-132.

Mel'čuk, Igor' A. (1985): Poverxnostnyj sintaksis russkix čislovyx vyraženij. = Wiener Slawistischer Almanach, Sonderband 16. Vienna.

Michaelis, Laura A. (2017): Meanings of Constructions. In Oxford Research Encyclopedia of Linguistics, DOI: http://dx.doi.org/10.1093/acrefore/9780199384655.013.309

Nesset, Tore (submitted): Cascading s-curves: the birth of a new paucal construction in Russian.

Pereltsvaig, Asya (2009): As Easy as Two, Three, Four? In: Wayles Browne, Adam Cooper, Alison Fisher, Esra Kesici, Nikola Predolac and Draga Zec (eds.): Annual Workshop on Formal Approaches to Slavic Linguistics: The Second Cornell Meeting 2009. Ann Arbor: Michigan Slavic Publications.

Steels, Luc (2013): Fluid Construction Grammar. In: Thomas Hoffmann and Graeme Taylor (eds.): The Oxford Handbook of Construction Grammar. Oxford: Oxford University Press. 
Stump, Gregory T. (2015). Inflectional Paradigms: Content and Form at the SyntaxMorphology. Cambridge: Cambridge University Press.

Timberlake, Alan (2004): A Reference Grammar of Russian. Cambridge: Cambridge University Press

Wade, Terence (2001): A comprehensive grammar of Russian. Oxford: Blackwell.

Zaliznjak, Andrej A. (1977): Grammatičeskij slovar' russkogo jazyka. Moscow: Russkij Jazyk.

Zaliznjak, Andrej A. (2002/1967): Russkoe imennoe slovoizmenenie. Moscow: Jazyki slavjanskoj kul'tury.

Zaliznjak, Andrej A. (2002/1977): Zakonomernosti akcentuacii russkix odnosložnyx suščestvitel'nyx mužskogo roda. Reprinted as an appendix to the 2002 edition of Russkoe imennoe slovoizmenenie. Moscow: Jazyki slavjanskoj kul'tury: 478-526. 